\title{
Zika Infection: Rubella Re-visited?
}

\author{
Richard E Winn MD, Phumpattra Chariyawong MD, Mark Lacy MD
}

What started in 1986 as a punchline to an infectious diseases Trivial Pursuit question or ABIM examination zebra has become the latest emerging infectious disease of worldwide significance. Zika virus introduction into the Americas where the population has no immunity has resulted in an epidemic of major proportions with considerable congenital impact. Thus far no significant disease has occurred in the United States, but the mosquito vector is present in sufficient numbers to enable transmission and disease appears inevitable at some point. Although microcephaly occurring as a result of gestational exposure remains controversial, there now exists scientific confirmation of central nervous system infection in laboratory animals, viral isolation from placental and fetal tissues, the development of congenital defects, and associations similar to consequences of rubella in women exposed in the early trimesters of pregnancy. ${ }^{1-4}$ Sexual transmission has also been confirmed.

An epidemic of microcephaly in Brazil has focused attention on this previously little known flavivirus which was originally described in Africa in the 1980 s. $^{4}$ The clinical disease in most infections appears similar to mild or subclinical Dengue virus infection ${ }^{1,5}$; in those whose herd immunity is high there appears to be little impact. In fact, no significant numbers of microcephaly cases have been described in the three or so decades since Zika's initial description in Africa, and few, if any, cases have been described in the countries surrounding Brazil. Other influences may be operable, including herbicides or pesticides which have been suggested as potential co-factors. Further investigation continues, and the public health importance is self-evident ${ }^{6}$, particularly as the Brazil Olympic Games loom.

Zika virus is a single-stranded positive RNA virus in the family Flaviviridae, genus Flavivirus, related to yellow fever, dengue and West Nile virus. It is transmitted by many Aedes spp. of mosquitoes. The virus was first identified in a febrile rhesus monkey during a yellow fever study in the Zika forest of Uganda in 1947 and was given the name of Zika virus. The first human infections were reported in 1952 in Uganda and in 1953 in Nigeria. ${ }^{1}$ Serologic surveillance has shown that Zika virus has circulated among people in Egypt, Nigeria, Uganda, India, Malaysia, Indonesia, Pakistan, Thailand, North Vietnam, and the Philippines, confirming the spread throughout tropical countries from Africa to Southeast Asia, west and north of the Wallace line without epidemics. ${ }^{8}$ In 2007, an outbreak was first reported in Yap Island (Micronesia). Common clinical manifestations were fever, rash, conjunctivitis, and arthralgia (confirmed by PCR). This outbreak represented the initial spread of the virus outside Africa. However, no mortality was observed. ${ }^{9}$ French Polynesia in the South Pacific saw the next outbreak in October of 2013, and infection was discovered during screening (RT-PCR) for a Dengue-like illness. The Zika strain was the same as occurred on Yap Island in $2007 . .^{10}$ The next outbreak was seen in New Caledonia with $99 \%$ identity to the Yap strain. Co-infection with dengue virus had been reported for two cases. ${ }^{11}$ The severity of infection and outcome did not appear to be worse with co-infection in those two cases.

The Americas never had documentation of Zika virus infection until febrile exanthems were observed at the end of 2014; the first confirmed case of Zika virus was reported in Brazil in March 2015. Transmission in Brazil was thought to be possibly related to the FIFA World Cup soccer competition in 2014. However, no Zika endemic Pacific Countries participated in the competition at that time. Another possible introduction was the Va'a World Sprint 
Championship canoe race in Rio de Janeiro, Brazil. Four Pacific countries in which Zika circulated during 2014, including French Polynesia, New Caledonia, Cook Islands, and Easter Island, had participated in this competition. ${ }^{12}$ Phylogenetic analysis showed that Zika sequences from the outbreak in Brazil belonged to the Asian lineage and showed $99 \%$ identity with a sequence from a Zika isolate from French Polynesia.

Zika virus has been detected in cerebrospinal fluid in several patients who were infected and exhibited neurological symptoms. Guillain-Barre and an acute multiple sclerosis-like syndrome have been observed with Zika virus. Due to the noted "epidemic" of microcephalic infants in Brazil, it appears that infected mothers may transmit Zika to gestating fetuses. ${ }^{13}$ Despite this observation, congenital abnormalities are not inevitable. After an outbreak in Brazil, Zika virus has rapidly spread through other countries of South America. By February 2016, 32 countries in the Americas had documented active transmission of Zika virus. ${ }^{14}$ The first confirmed case of locally acquired Zika viral infection in the United States was also reported in February 2016 in Texas. Transmission occurred after sexual occurrence with a contact incubating infection after travel to Venezuela. ${ }^{15}$ The incubation period isn't determined precisely, but if it parallels other flaviviruses, it would be about 1 week ( 3 days to 2 weeks). ${ }^{5}$ Transmission has been documented through blood transfusion in Brazil which is not unexpected due to the viremia. ${ }^{16}$ No consistent serologic donor screening is in place yet. No serologic test for Zika virus is commercially available, but the Texas State Health Department and the U.S. Centers for Disease Control have the capacity to analyze samples from patients with suspected infection. Cross reactivity with other flaviviruses, such as dengue virus, may occur.

Although the clinical impact of this infection in adults from initial reports appears to be minimal ${ }^{5}$ (less than the described clinical syndrome in dengue), the overall clinical impact remains to be defined. The potential linkage to significant congenital anomalies warrants careful surveillance and monitoring in pregnant females and is analogous to the concerns for rubella transmission and outcomes in the 1950s and 1960s. There is no treatment or vaccine available. For now until these developments occur, public health measures for prevention, particularly in pregnancy, will remain of utmost importance. ${ }^{6}$

\begin{abstract}
Author Affiliation: Phumpattra Chariyawong is a resident in Internal Medicine at Texas Tech University Health Sciences Center in Lubbock, TX. Richard E Winn and Mark Lacy are Infectious Disease specialists in the Department of Internal Medicine at TTUHSC in Lubbock, TX.

Received: 04/26/2016

Accepted: 05/24/2016

Published electronically: 07/15/2016

Conflict of Interest Disclosures: none

Corresponding Author : Richard E Winn MD

Contact Information: Richard.winn@ttuhsc.edu

DOI: 10.12746/swrccc2016.0415.192
\end{abstract}

\section{REFERENCES}

1. Petersen LR, Jamieson DJ, Powers AM and Honein MA. Zika virus. NEJM. 2016; 374:1552-1563.

2. Citil-Dogan A, Wayne S, Bauer S, Ogunyemi D, Kulkharni SK, Maulik D, Carpenter CF and Bahado-Singh RO. The Zika virus and pregnancy: evidence, management and prevention. $J$ Matern Fetal Neonatal Med. 2016 Apr 7:1-41.

3. Rasmussen SA, Jamieson DJ, Honein MA and Petersen LR. NEJM. Zika virus and birth defects-reviewing the evidence for causality. N Engl J Med. 2016 Apr 13:1-7.

4. Nunes ML, Carlini CR, Marinowic D, Neto FK, Fiori HH, Scotta MC, Zanella PL, Soder RB, da Costa JC. Microcephaly and Zika virus: a clinical and epidemiological analysis of the current outbreak in Brazil. J Pediatr (Rio J). 2016 Apr 14. pii: S0021-7557.

5. Sampathkumar P, Sanchez JL. Zika Virus in the Americas: a review for clinicians. Mayo Clin Proc. 2016 Apr; 91(4):514-21.

6. Focosi D, Maggi F, Pistello M. Zika virus: implications for public health. Clin Infect Dis. 2016 Apr 5:1-19.

7. Gubio S. Campos, Antonio C. Bandeira, and Silvia I. Sardi. Zika virus outbreak, Bahia, Brazil. Emerg Infect Dis 2015 Oct; 21(10): 1885-1886. 
8. Lanciotti RS1, Kosoy OL, Laven JJ, Velez JO, Lambert AJ, Johnson AJ, Stanfield SM, Duffy MR. Genetic and serologic properties of Zika virus associated with an epidemic, Yap State, Micronesia, 2007. Emerg Infect Dis. 2008 Aug; 14(8):1232-9.

9. Duffy MR1, Chen TH, Hancock WT, Powers AM, Kool JL, Lanciotti RS, Pretrick M, Marfel M, Holzbauer S, Dubray C, Guillaumot L, Griggs A, Bel M, Lambert AJ, Laven J, Kosoy O, Panella A, Biggerstaff BJ, Fischer M, Hayes EB. Zika virus outbreak on Yap Island, Federated States of Micronesia. $N$ Engl $J$ Med. 2009 Jun 11; 360(24):2536-43.

10. Cao-Lormeau VM, Roche C, Teissier A, Robin E, Berry AL, Mallet HP, Sall AA, Musso D. Zika virus, French Polynesia, South pacific, 2013. Emerg Infect Dis. 2014 Jun; 20(6):1085-6.

11. Dupont-Rouzeyrol M, O'Connor O, Calvez E, Daurès M, John M, Grangeon JP, Gourinat AC. Co-infection with Zika and dengue viruses in 2 patients, New Caledonia, 2014. Emerg Infect Dis. 2015 Feb; 21(2):381-2.

12. Musso D. Zika Virus Transmission from French Polynesia to Brazil. Emerg Infect Dis. 2015 Oct;21(10):1887.

13. Heukelbach J1, Alencar CH, Kelvin AA, De Oliveira WK, Pamplona de Góes Cavalcanti L. Zika virus outbreak in Brazil. $J$ Infect Dev Ctries. 2016 Feb 28;10(2):116-20.

14. Meaney-Delman D, Hills SL, Williams $C$, Galang RR, Iyengar P, Hennenfent AK, Rabe IB, Panella A, Oduyebo T, Honein MA, Zaki S, Lindsey N, Lehman JA, Kwit N, Bertolli J, Ellington S, Igbinosa I, Minta AA, Petersen EE, Mead P, Rasmussen SA, Jamieson DJ. Zika virus infection among U.S. pregnant travelers - August 2015-February 2016. MMWR Morb Mortal Wkly Rep. 2016 Mar 4; 65(8):211-4.

15. McCarthy M1. Zika virus was transmitted by sexual contact in Texas, health officials report. BMJ. $2016 \mathrm{Feb} 4 ; 352: 1720$.

16. Boadle A. Brazil reports Zika infection from blood transfusions. Reuters website. http://www.reuters.com/article/us-healthzikabrazil-blood-idUSKCNOVD22N. Published February 4, 2016. 